\title{
OPTIMASI FORMULA KRIM DAUN JENGKOL (Pithecollobium lobatum Benth) SEBAGAI ANTIBAKTERI MENGGUNAKAN DESAIN FAKTORIAL
}

\author{
Kiki Puspitasary ${ }^{1, *}$, Ilham Kuncahyo², Mamik Ponco Rahayu ${ }^{3}$ \\ ${ }^{1}$ STIKES Mamba'ul 'Ulum Surakarta \\ ${ }^{2,3}$ Universitas Setia Budi \\ ${ }^{1}$ kiki.puspi@gmail.com*
}

\begin{abstract}
Abstrak
Latar belakang : Daun jengkol (Pithecollobium lobatum Benth) merupakan bahan obat tradisional yang digunakan oleh masyarakat sebagai obat eksim, kudis, luka dan bisul, kulit buahnya untuk borok. Daun jengkol mengandung saponin, flavonoid dan tanin. Menurut Salni (2011) fraksi etil asetat daun jengkol pada konsentrasi 160 ppm mempunyai aktivitas antibakteri terhadap Staphylococcus aureus ATCC 25923.
\end{abstract}

Tujuan Penelitian : Penelitian ini untuk mendapatkan formula optimum krim ekstrak daun jengkol dan mengetahui aktivitas antibakteri terhadap Staphylococcus aureus ATCC 25923.

Metode : Ekstraksi diawali dari pelarut n-heksan kemudian etil asetat. Ekstrak etil asetat dipekatkan dengan evaporator kemudian digunakan sebagai zat aktif dalam pembuatan krim. Krim ekstrak daun jengkol dibuat empat formula berdasarkan metode desain faktorial. Krim yang dihasilkan diuji sifat fisiknya meliputi organoleptis, viskositas, daya sebar, daya lekat. Formula optimum berdasarkan parameter sifat fisik krim yaitu: viskositas, daya sebar, daya lekat diperoleh menggunakan software Design Ease ${ }^{\circledR}$ versi 7.1.6. Formula optimum yang diperoleh dibuat dan diuji sifat fisiknya selama 4 minggu serta aktivitas antibakterinya menggunakan metode difusi.

Hasil : Formula optimum krim ekstrak daun jengkol diperoleh pada proporsi polisorbat 60 sebesar $0,41 \mathrm{~g}$ dan sorbitan 60 sebesar 1,19 g. Respon sifat fisik formula optimum dari hasil prediksi dan percobaan menunjukkan tidak ada beda signifikan. Aktivitas antibakteri krim optimum sebesar 15,3 mm.

Simpulan : Ekstrak daun jengkol dapat dibuat krim dengan formula optimum dengan sifat fisik yang baik melalui pengujian beberapa formula menggunakan desain faktorial.

Kata kunci : daun jengkol; polisorbat 60; sorbitan 60; Staphylococcus aureus

OPTIMIZATION OF THE JENGKOL LEAF (PITHECOLLOBIUM LOBATUM BENTH) CREAM FORMULA AS AN ANTIBACTERIA USING FACTORIAL DESIGN

Abstract
Background : Jengkol leaf (Pithecollobium lobatum Benth) is a traditional
medicinal ingredient used by the community as a drug for eczema, scabies, sores
and ulcers, the fruit's skin for ulcers. Jengkol leaves contain saponins, flavonoids 
and tannins. According to Salni (2011) the ethyl acetate fraction of jengkol leaves at a concentration of $160 \mathrm{ppm}$ has antibacterial activity against Staphylococcus aureus ATCC 25923.

Research purposes : This research is to get the optimum formula of jengkol leaf extract cream and to know the antibacterial activity against Staphylococcus aureus ATCC 25923.

Method : Extraction begins with n-hexane then ethyl acetate. Ethyl acetate extract was concentrated with an evaporator and then used as an active ingredient in making creams. Jengkol leaf extract cream is made of four formulas based on factorial design methods. The resulting creams were tested for their physical properties including organoleptic, viscosity, dispersibility, adhesion. The optimum formula is based on the parameters of the physical properties of the cream, namely: viscosity, diffusion power, adhesion, obtained using Design Ease $®$ software version 7.1.6. The optimum formula obtained was made and tested for its physical properties for 4 weeks and its antibacterial activity using the diffusion method.

Results : The optimum formula of jengkol leaf extract cream was obtained at the proportion of polysorbate 60 by $0.41 \mathrm{~g}$ and sorbitan 60 by $1.19 \mathrm{~g}$. The response of the optimum physical properties of the formula from the results of the predictions and experiments showed no significant difference. The antibacterial activity of the optimum cream formula is $15.3 \mathrm{~mm}$.

Conclusion : Jengkol leaf extract can be made with optimum formula cream with good physical properties through testing several formulas using a factorial design.

Key words : Jengkol leaf extract; factorial design; cream; Staphylococcus aureus

\section{PENDAHULUAN}

Infeksi kulit yang disebabkan oleh bakteri banyak diderita penduduk di negara-negara beriklim tropis seperti Indonesia. Pada umumnya penyakit ini banyak terdapat di daerah pemukiman padat penduduk dengan tingkat kebersihan lingkungan yang masih kurang. Penyakit infeksi pada kulit tersebut antara lain kudis, bisul, dan borok. Bakteri yang menyebabkan infeksi pada kulit adalah Staphylococcus aureus. Bakteri ini mampu berkembang biak dan menyebar luas dalam jaringan dengan membentuk zat ekstraseluler antara lain eksotoksin, enterotoksin, lekosidan, koagulase. Infeksi kulit akibat $S$. aureus yang paling sering mengalami penyebaran dengan cepat ke orang lain (Amalia, 2013).

Sejak jaman dahulu pengobatan menggunakan tanaman sudah menjadi pilihan masyarakat untuk mengobati berbagai penyakit. Penelitian yang bertujuan untuk menemukan obat-obat baru dengan bahan utama dari tanaman sudah banyak dilakukan. Salah satunya adalah daun jengkol. Daun jengkol secara empiris mampu menyembuhkan infeksi pada kulit. Cara pengolahannya adalah sekitar 10 gram daun jengkol kering di bakar, abunya diseduh dengan 2 gelas air panas, kemudian disaring. Hasil saringannya digunakan untuk mencuci bagian kulit yang terinfeksi. 
Kandungan kimia dari daun jengkol telah diuji dan terbukti mengandung flavonoid, tanin, dan saponin. Kandungan flavonoid dapat digunakan sebagai antibakteri (Yunitasari, et al. 2016). Penyakit kudis, bisul, dan borok disebabkan oleh bakteri. Bakteri tersebut adalah Staphylococcus aureus, bakteri ini terdapat pada kulit. Fraksi etil asetat daun jengkol pada konsentrasi 160 ppm mampu membunuh pertumbuhan bakteri Staphylococcus aureus (Salni, 2011). Ekstrak etil asetat didapatkan dengan metode soxhlet.

Bentuk sediaan berupa krim dianggap sesuai bila digunakan pada kulit yang mengalami infeksi oleh bakteri (Ali, et al. 2013). Basis krim yang akan digunakan dalam penelitian ini adalah basis air dalam minyak. Emulgator yang digunakan adalah kombinasi polisorbat 60 dan sorbitan 60 dengan pertimbangan mudah didapat dan bersifat stabil tidak bereaksi dengan berbagai macam zat aktif (Ansel, 2014). Optimasi diperlukan dalam penelitian ini agar komposisi polisorbat dan sorbitan yang digunakan dapat tepat sehingga menjadi krim dengan sifat fisik yang baik.

Penelitian ini bertujuan untuk menentukan formula krim yang mempunyai sifat fisik baik sehingga mampu memberikan efek terapi yang maksimal. Optimasi formula krim menggunakan metode desain factorial. Desain faktorial digunakan dalam percobaan untuk menentukan secara simulasi efek dari beberapa faktor dan interaksinya yang signifikan. Sehingga pada akhirnya akan didapatkan formula krim yang paling optimum dengan stabilitas yang baik (Suwanda, 2011). Pengujian aktivitas antibakteri terhadap krim menggunakan metode difusi untuk mengetahui diameter zona hambat.

\section{METODE \\ Identifikasi Kandungan Kimia Serbuk Daun Jengkol \\ Identifikasi saponin. dilakukan dengan serbuk jengkol dimasukkan kedalam} tabung reaksi, kemudian ditambah $10 \mathrm{ml}$ air panas dan dibiarkan menjadi dingin, dikocok selama 10 detik. Reaksi positif ditunjukkan dengan terbentuknya buih yang mantap selama tidak kurang dari 10 menit setinggi $1-10 \mathrm{~cm}$. Pada penambahan 1 tetes asam klorida $2 \mathrm{~N}$ buih tidak hilang (Maxiselly, et al. 2015).

Identifikasi flavonoid. Larutan A sebanyak $5 \mathrm{ml}$ dimasukkan dalam tabung reaksi, ditambah $0,1 \mathrm{~g}$ serbuk $\mathrm{Mg}, 2 \mathrm{ml}$ larutan alkohol : asam klorida (1:1) dan pelarut amil alkohol. Campuran dikocok kuat-kuat kemudian dibiarkan memisah. Reaksi positif ditunjukkan adanya warna merah atau kuning atau jingga pada lapisan amil alkohol (Maxiselly, et al. 2015).

Identifikasi tanin. Serbuk daun jengkol ditambah $10 \mathrm{ml}$ air panas kemudian didihkan selama 15 menit dan saring. Filtrat yang diperoleh disebut larutan B. Sebanyak $5 \mathrm{ml}$ larutan B ditambah pereaksi besi (III) klorida 1\%. Reaksi positif ditunjukkan dengan terbentuknya warna violet (Maxiselly, et al. 2015).

\section{Pembuatan Ekstrak Etil Asetat Daun Jengkol}

Pembuatan ekstrak daun jengkol menggunakan metode sokhlet. Serbuk daun jengkol sebanyak 50 gram dimasukkan pada kertas saring dan diikat dengan tali, dimasukkan ke dalam alat soxhlet yang diisi dengan n-heksan sebanyak satu setengah kali sirkulasi lalu dihubungkan dengan pendingin balik serta pipa air. Larutan penyari yang terkumpul dalam badan soxhlet dan telah mencapai tinggi 
maksimum, otomatis akan turun ke dalam labu alas bulat. Ekstraksi dilakukan sampai cairan penyari menjadi jernih, dari hasil ekstraksi tersebut didapat ampas dan filtrat. Ampas yang didapat dikering anginkan kemudian diekstraksi lagi seperti cara di atas dengan menggunakan pelarut etil asetat. Setelah didapat filtratnya dipekatkan dengan rotary evaporator sehingga didapat ekstrak etil asetat (Badan POM RI, 2012).

\section{Rancangan Formula Krim}

Tabel 1. Rancangan formula sediaan krim ekstrak daun jengkol sesuai rancangan desain faktorial $(\%)$

\begin{tabular}{ccccc}
\hline Bahan & Formula $(\mathbf{1})$ & Formula a & Formula b & Formula ab \\
\hline Ekstrak daun jengkol & 3,13 & 3,13 & 3,13 & 3,13 \\
Setil alcohol & 2 & 2 & 2 & 2 \\
Parafin cair & 18 & 18 & 18 & 18 \\
Asam stearat & 13 & 13 & 13 & 13 \\
Lanolin anhidrat & 3 & 3 & 3 & 3 \\
Propilen glikol & 10 & 10 & 10 & 10 \\
Polisorbat 60 & 3,47 & 4,25 & 3,47 & 4,25 \\
Sorbitan 60 & 1,32 & 1,32 & 2 & 2 \\
Natrium EDTA & 0,1 & 0,1 & 0,1 & 0,1 \\
a-Tokoferol & 0,02 & 0,02 & 0,02 & 0,02 \\
Oleum rosae & $5 \mathrm{gtt}$ & $5 \mathrm{gtt}$ & $5 \mathrm{gtt}$ & $5 \mathrm{gtt}$ \\
Aquadest ad & 100 & 100 & 100 & 100 \\
\hline
\end{tabular}

\section{Pembuatan krim}

Fase minyak dibuat dengan melebur asam stearat, setil alkohol, parafin cair, lanolin anhidrat, $\alpha$-tokoferol, sorbitan 60 , dan esktrak etil asetat pada suhu $70^{\circ} \mathrm{C}$. Fase air dibuat dengan memanaskan propilen glikol, polisorbat 60 , air, dan natrium EDTA pada suhu $70^{\circ} \mathrm{C}$. Krim dibuat dengan cara mencampurkan fase minyak sedikit demi sedikit ke dalam fase air sambil diaduk dengan pengaduk sampai terbentuk emulsi (basis krim). Sisa air ditambahkan kemudian diaduk sampai homogen. oleum rosae ditambahkan terakhir karena berfungsi sebagai corrigen saporis (Anwar, 2012).

Pengujian sifat fisik krim

Uji homogenitas krim :

Uji homogenitas krim dilakukan menggunakan tiga buah gelas objek. Masingmasing krim dioleskan pada gelas objek dan dilihat homogenitasnya. Sediaan dikatakan homogen bila tidak ada perbedaan warna yang terlihat pada gelas objek (Rosmala, et al. 2014).

Uji daya sebar krim :

Uji daya sebar krim dilakukan menggunakan alat khusus uji daya sebar, yaitu dua buah kaca bulat yang pada dasarnya terdapat lingkaran-lingkaran pengukur daya sebar. Uji ini dilakukan 3 kali replikasi. Daya sebar dinyatakan dalam satuan $\mathrm{cm}$ (Rosmala, et al. 2014).

Uji daya lekat krim :

Uji daya lekat krim dilakukan menggunakan dua buah gelas objek yang pada salah satu ujung gelas objek diberikan beban seberat 80 gram. Uji ini dilakukan 3 kali replikasi (Rosmala, et al. 2014). 


\section{Uji viskositas :}

Uji viskositas menggunakan alat viscometer Cup and Bob atau viscometer VT-04 E RION., Ltd. Masing-masing dilakukan 3 kali replikasi (Rosmala, et al. 2014).

\section{Penentuan formula optimum :}

Penentuan formula optimum menggunakan metode desain factorial. Dengan sebuah program dari Software Design Ease ${ }^{\circledR}$ versi 7.1.6 dapat ditentukan formula optimum krim yang mempunyai stabilitas baik.

\section{Pengujian aktivitas antibakteri :}

Pengujian aktivitas antibakteri menggunakan metode difusi. Cara metode ini adalah menyelupkan kapas lidi steril pada suspensi yang telah dibuat dan ditekantekan pada ujung tabung, dioleskan pada media MHA (Muller Hinton Agar) sampai rata. Jumlah bakteri yang digunakan disesuaikan dengan kekeruhan Standart Brown II yang diangkat setara dengan 785 juta bakteri Staphylococcus aureus per mili. Pada media tersebut dibuat sumuran dengan menggunakan boor prop. Masa inkubasi 24 jam pada suhu $37^{\circ} \mathrm{C}$, diamati daerah hambatannya. Daerah yang ditumbuhi bakteri disekitar sumuran yang berisi krim uji menandakan bahwa kandungan kimia daun jengkol memiliki daya hambat terhadap bakteri uji (Wahyuning, et al. 2016).

\section{HASIL DAN PEMBAHASAN}

Hasil identifikasi kandungan kimia serbuk daun jengkol

Berikut adalah hasil identifikasi kandungan kimia serbuk daun jengkol :

Tabel 2. Hasil Identifikasi Kandungan kimia daun jengkol.

\begin{tabular}{|c|c|c|c|c|}
\hline No. & $\begin{array}{c}\text { Kandungan } \\
\text { kimia }\end{array}$ & Identifikasi & $\begin{array}{c}\text { Hasil } \\
\text { pengamatan }\end{array}$ & $\begin{array}{c}\text { Pustaka } \\
\text { (Anonim 1977) }\end{array}$ \\
\hline 1. & Saponin & $\begin{array}{l}\text { Serbuk ditambah } 10 \mathrm{ml} \\
\text { air panas, dinginkan dan } \\
\text { dikocok kuat-kuat }+1 \\
\text { tetes } \mathrm{HCl} 2 \mathrm{~N} .\end{array}$ & $\begin{array}{l}\text { Terbentuk buih } \\
\text { yang konstan }\end{array}$ & $\begin{array}{l}\text { Terbentuk busa yang } \\
\text { mantap }+1 \text { tetes } \mathrm{HCl} \\
2 \mathrm{~N} \text { busa tidak hilang }\end{array}$ \\
\hline 2. & Flavonoid & $\begin{array}{c}\text { filtrat ditambah serbuk } \\
\text { Mg+alkohol kemudian } \\
\text { kocok }\end{array}$ & $\begin{array}{l}\text { Warna merah } \\
\text { pada lapisan } \\
\text { amil alkohol }\end{array}$ & $\begin{array}{l}\text { Warna merah pada } \\
\text { lapisan amil alkohol }\end{array}$ \\
\hline 3. & Tanin & $\begin{array}{c}\text { Filtrat ditambah aquadest } \\
\text { panas kemudian } \\
\text { ditambah } \mathrm{FeCl}_{3} 1 \%\end{array}$ & $\begin{array}{l}\text { Warna biru } \\
\text { kehitaman }\end{array}$ & $\begin{array}{l}\text { Warna hijau, biru } \\
\text { atau kehitaman }\end{array}$ \\
\hline
\end{tabular}

\section{Pembuatan Ekstrak Etil Asetat Daun Jengkol}

Pembuatan ekstrak etil asetat daun jengkol dengan metode soxhletasi bertingkat dilakukan dua kali replikasi dan diperoleh rata-rata rendemen $8,96 \%$. Hasil perhitungan rendemen daun jengkol ditunjukkan oleh tabel 2.

Tabel 3. Hasil prosentase rendemen ekstrak soxhlet daun jengkol.

\begin{tabular}{cccc}
\hline Pelarut & Serbuk (gram) & Ekstrak (gram) & Rendemen $(\% \mathbf{~ b} / \mathbf{b})$ \\
\hline n-heksan & 201,57 & 17,46 & 8,66 \\
Etil asetat & 201,25 & 18,05 & 8,96 \\
\hline
\end{tabular}

Hasil pengujian sifat fisik krim ekstrak daun jengkol 


\section{Hasil Pengujian Homogenitas Krim :}

Hasil pengujian homogenitas krim ekstrak daun jengkol dapat dilihat pada table 5.

Tabel 4. Hasil homogenitas sediaan krim ekstrak daun jengkol dengan berbagai konsentrasi polisorbat 60 dan sorbitan 60.

\begin{tabular}{ccccc}
\hline Formula & Formula 1 & Formula a & Formula b & Formula ab \\
\hline Minggu 0 & Homogen & Homogen & Homogen & Homogen \\
Minggu 1 & Homogen & Homogen & Homogen & Homogen \\
Minggu 2 & Homogen & Homogen & Homogen & Homogen \\
Minggu 3 & Homogen & Homogen & Homogen & Homogen \\
\hline
\end{tabular}

Hasil pengamatan terhadap homogenitas warna krim esktrak daun jengkol menunjukkan bahwa keempat formula memiliki homogenitas warna yang baik karena warna hijau yang merata pada basisnya selain itu selama penyimpanan pada suhu kamar tidak mengalami perubahan fisik dalam hal homogenitasnya. Hal ini disebabkan pada proses pembuatan krim semua bahan yang digunakan untuk pembuatan krim ekstrak daun jengkol ini tercampur dengan sempurna sehingga menghasilkan produk yang homogen.

\section{Pengujian Daya Sebar Krim :}

Hasil pengujian daya sebar krim dapat dilihat pada table 5 berikut ini :

Tabel 5. Hasil daya sebar sediaan krim ekstrak daun jengkol dengan berbagai konsentrasi polisorbat 60 dan sorbitan 60 .

\begin{tabular}{cccccc}
\hline \multirow{2}{*}{ Formula } & \multicolumn{5}{c}{ Diameter penyebaran $(\mathbf{c m} \pm$ SD) } \\
\cline { 2 - 6 } & Beban & Minggu 0 & Minggu 1 & Minggu 2 & Minggu 3 \\
\hline Formula I & 55,46 & $2,08 \pm 0,06$ & $1,64 \pm 0,03$ & $1,80 \pm 0,09$ & $1,66 \pm 0,05$ \\
& 105,46 & $2,13 \pm 0,10$ & $1,73 \pm 0,05$ & $1,90 \pm 0,08$ & $1,75 \pm 0,05$ \\
& 155,46 & $2,16 \pm 0,11$ & $1,80 \pm 0,04$ & $2,00 \pm 0,09$ & $1,83 \pm 0,06$ \\
& 205,46 & $2,28 \pm 0,10$ & $1,87 \pm 0,02$ & $2,10 \pm 0,09$ & $1,93 \pm 0,03$ \\
\hline Formula A & 55,46 & $2,06 \pm 0,02$ & $1,60 \pm 0,04$ & $1,80 \pm 0,09$ & $1,63 \pm 0,07$ \\
& 105,46 & $2,12 \pm 0,05$ & $1,60 \pm 0,10$ & $1,90 \pm 0,09$ & $1,73 \pm 0,03$ \\
& 155,46 & $2,15 \pm 0,07$ & $1,75 \pm 0,08$ & $1,90 \pm 0,11$ & $1,78 \pm 0,02$ \\
Formula B & 205,46 & $2,18 \pm 0,06$ & $1,80 \pm 0,10$ & $2,00 \pm 0,08$ & $1,88 \pm 0,02$ \\
\hline Formula & 55,46 & $2,23 \pm 0,15$ & $1,60 \pm 0,08$ & $1,80 \pm 0,03$ & $1,66 \pm 0,05$ \\
AB & 105,46 & $2,25 \pm 0,17$ & $1,70 \pm 0,02$ & $1,93 \pm 0$ & $1,76 \pm 0,05$ \\
& 155,46 & $2,25 \pm 0,16$ & $1,80 \pm 0,05$ & $1,90 \pm 0,12$ & $1,81 \pm 0,03$ \\
& 205,46 & $2,30 \pm 0,17$ & $1,90 \pm 0,08$ & $2,00 \pm 0,09$ & $1,88 \pm 0,07$ \\
\hline & 55,46 & $1,80 \pm 0,02$ & $1,50 \pm 0,10$ & $1,65 \pm 0,02$ & $1,62 \pm 0,02$ \\
& 105,46 & $1,95 \pm 0,02$ & $1,60 \pm 0,10$ & $1,74 \pm 0,03$ & $1,73 \pm 0,05$ \\
& 155,46 & $2,02 \pm 0,02$ & $1,80 \pm 0,01$ & $1,84 \pm 0,08$ & $1,83 \pm 0,05$ \\
& 205,46 & $2,10 \pm 0$ & $1,90 \pm 0,03$ & $1,95 \pm 0,10$ & $1,93 \pm 0,03$ \\
\hline
\end{tabular}

Hasil pengukuran terhadap daya sebar krim menunjukkan bahwa keempat formula cenderung mengalami penurunan daya sebar. Penurunan daya sebar tersebut disebabkan oleh peningkatan viskositas. 


\section{Hasil Pengujian Daya Lekat Krim :}

Tabel 6. Hasil daya lekat krim ekstrak daun jengkol dengan berbagai konsentrasi polisorbat 60 dan sorbitan 60.

\begin{tabular}{ccccc}
\hline $\begin{array}{c}\text { Pemeriksaan } \\
\text { waktu }\end{array}$ & $\begin{array}{c}\text { Formula I } \\
\text { (menit) }\end{array}$ & $\begin{array}{c}\text { Formula A } \\
\text { (menit) }\end{array}$ & $\begin{array}{c}\text { Formula B } \\
\text { (menit) }\end{array}$ & $\begin{array}{c}\text { Formula AB } \\
\text { (menit) }\end{array}$ \\
\hline Minggu 0 & $1,12 \pm 0,30$ & $1,29 \pm 0,20$ & $1,10 \pm 0,30$ & $1,08 \pm 0,03$ \\
Minggu 1 & $1,38 \pm 0,05$ & $1,31 \pm 0,11$ & $1,29 \pm 0,19$ & $1,54 \pm 0,01$ \\
Minggu 2 & $1,26 \pm 0,04$ & $1,25 \pm 0,04$ & $1,31 \pm 0,04$ & $1,40 \pm 0,03$ \\
Minggu 3 & $1,38 \pm 0,02$ & $1,35 \pm 0,03$ & $1,40 \pm 0,04$ & $1,47 \pm 0,04$ \\
\hline
\end{tabular}

Pengamatan daya lekat krim tiap minggu menunjukkan bahwa semakin besar konsentrasi polisorbat 60 dan sorbitan 60 yang digunakan semakin besar daya lekat. Serta adanya kecenderungan peningkatan daya lekat krim dari penyimpanan tiap minggunya. Hal ini dapat disebabkan karena terjadinya perubahan viskositas. Jika dibandingkan dengan data viskositas menunjukan bahwa semakin besar viskositas maka semakin besar daya lekat suatu krim.

\section{Hasil Pengujian Viskositas Krim :}

Viskositas sediaan berhubungan terhadap kemudahan sediaan dari pemakaian suatu sediaan. Viskositas krim harus dapat membuat krim untuk mudah diambil dari wadahnya dan mudah dioleskan, namun tetap menempel pada kulit. Viskositas sangat berpengaruh terhadap efektivitas terapi yang diinginkan serta kenyamanan dalam penggunaan sehingga tidak boleh terlalu keras dan terlalu encer. Hasil pengujian viskositas tersaji pada tabel 8 .

Tabel 7. Hasil viskositas sediaan krim ekstrak daun jengkol dengan berbagai konsentrasi polisorbat 60 dan sorbitan 60 .

\begin{tabular}{ccccc}
\hline $\begin{array}{c}\text { Pemeriksaan } \\
\text { waktu }\end{array}$ & $\begin{array}{c}\text { Formula I } \\
\text { (d Pas) }\end{array}$ & $\begin{array}{c}\text { Formula A } \\
\text { (d Pas) }\end{array}$ & $\begin{array}{c}\text { Formula B } \\
\text { (d Pas) }\end{array}$ & $\begin{array}{c}\text { Formula AB } \\
\text { (d Pas) }\end{array}$ \\
\hline Minggu 0 & $208,30 \pm 14,40$ & $260,00 \pm 10,00$ & $316,60 \pm 28,80$ & $358,30 \pm 38,10$ \\
Minggu 1 & $413,30 \pm 32,10$ & $383,30 \pm 30,80$ & $416,60 \pm 76,30$ & $556,60 \pm 49,30$ \\
Minggu 2 & $426,60 \pm 30,50$ & $433,30 \pm 28,80$ & $433,30 \pm 57,70$ & $550,00 \pm 50,00$ \\
Minggu 3 & $433,30 \pm 28,80$ & $408,80 \pm 38,10$ & $533,30 \pm 28,80$ & $550,00 \pm 50,00$ \\
\hline
\end{tabular}

Hasil pengamatan terhadap viskositas krim menunjukkan bahwa viskositas keempat formula dari minggu pertama mengalami kenaikan. Hal tersebut disebabkan proses pembuatan krim yang dipengaruhi oleh pengadukan ketika proses pencampuran. Selain itu juga dipengaruhi oleh kondisi penyimpanan. Perbedaan viskositas dari masing-masing formula dapat disebabkan oleh perbedaan konsentrasi emulgator yang digunakan. Dalam penelitian ini konsentrasi emulgator yang semakin tinggi menyebabkan viskositas menjadi besar.

\section{Penentuan Formula Optimum :}

Optimasi dilakukan dengan aplikasi desain faktorial, dimana polisorbat 60 dan sorbitan 60 merupakan parameter yang akan diteliti pengaruhnya terhadap kualitas krim yang diwakili oleh viskositas, daya sebar, dan daya lekat yang kemudian disebut respon. Pada penelitian diperoleh hasil uji sifat fisik krim seperti terlihat 
pada tabel 8. Optimasi dengan desain faktorial dapat dilihat pada tabel 9. Efek yang bertanda positif pada persamaan menunjukkan efek faktor atau interaksi berpengaruh positif (memperbesar respon), sedangkan efek yang bertanda negatif menunjukkan bahwa faktor atau interaksi berpengaruh negatif (memperkecil respon), untuk mengetahui signifikasi pengaruh faktor atau interaksi tersebut maka dilanjutkan uji dengan software desigen Ease Versi 7.1.6.

Tabel 8. Hasil pengukuran uji sifat fisik krim ekstrak daun jengkol pada pengujian minggu pertama.

\begin{tabular}{lllll}
\hline \multicolumn{1}{c}{ Sifat fisik } & \multicolumn{1}{c}{$\mathbf{F}(\mathbf{I})$} & \multicolumn{1}{c}{$\mathbf{F}(\mathbf{a})$} & \multicolumn{1}{c}{$\mathbf{F}(\mathbf{b})$} & \multicolumn{1}{c}{$\mathbf{F}(\mathbf{a b})$} \\
\hline Viskositas (d Pas) & $208,3 \pm 14,4$ & $260,0 \pm 10,0$ & $316,6 \pm 28,8$ & $358,30 \pm 38,1$ \\
Daya sebar (cm) & $2,15 \pm 0,11$ & $2,15 \pm 0,07$ & $2,25 \pm 0,16$ & $2,02 \pm 0,02$ \\
Daya lekat (menit) & $1,12 \pm 0,3$ & $1,29 \pm 0,2$ & $1,10 \pm 0,3$ & $1,08 \pm 0,03$ \\
\hline
\end{tabular}

Tabel 9. Hasil evaluasi karakter fisik krim berdasarkan rumus metode desain faktorial $2^{2}$.

\begin{tabular}{ccccccc}
\hline Formula & $\begin{array}{c}\text { Faktor A } \\
\text { Polisorbat } \\
60\end{array}$ & $\begin{array}{c}\text { Faktor B } \\
\text { Sorbitan } \\
\text { 60 }\end{array}$ & $\begin{array}{c}\text { Interaksi } \\
\text { A dan B }\end{array}$ & $\begin{array}{c}\text { Viskositas } \\
\text { (d Pas) }\end{array}$ & $\begin{array}{c}\text { Respon } \\
\text { sebar } \\
\text { (cm) }\end{array}$ & $\begin{array}{c}\text { Daya lekat } \\
\text { (menit) }\end{array}$ \\
\hline I & -1 & -1 & +1 & 208,3 & 2,15 & 1,12 \\
$\mathrm{~A}$ & -1 & +1 & -1 & 260,0 & 2,15 & 1,29 \\
$\mathrm{~B}$ & +1 & -1 & -1 & 316,6 & 2,25 & 1,10 \\
$\mathrm{Ab}$ & +1 & +1 & +1 & 358,3 & 2,02 & 1,08 \\
\hline
\end{tabular}

Hasil perhitungan efek faktor terhadap sifat fisik krim berdasarkan desain faktorial dapat dilihat pada tabel 10 di bawah ini :

Tabel 10. Hasil perhitungan efek polisorbat 60 , sorbitan 60 dan interaksi dari keduanya terhadap sifat fisik krim.

\begin{tabular}{lccc}
\hline Sifat fisik & Efek a & Efek b & Interaksi a-b \\
\hline Viskositas & 46,7 & 103,3 & -5 \\
Daya sebar & $-0,115$ & $-0,015$ & 0,89 \\
Daya lekat & 0,075 & $-0,115$ & $-0,095$ \\
\hline
\end{tabular}

Keterangan efek a $=$ Polisorbat 60

efek $b=$ Sorbitan 60

efek $\mathrm{a}-\mathrm{b}=$ efek interaksi keduanya

Dari pengukuran karakteristik sifat fisik krim yang terdiri dari viskositas, daya sebar, daya lekat krim dapat dibuat contour plot. Pembuatan contour plot didasarkan pada perhitungan persamaan desain faktorial. Pada contour plot masing-masing uji sifat fisik tersebut ditentukan area optimum untuk memperoleh hasil seperti yang dikehendaki. 

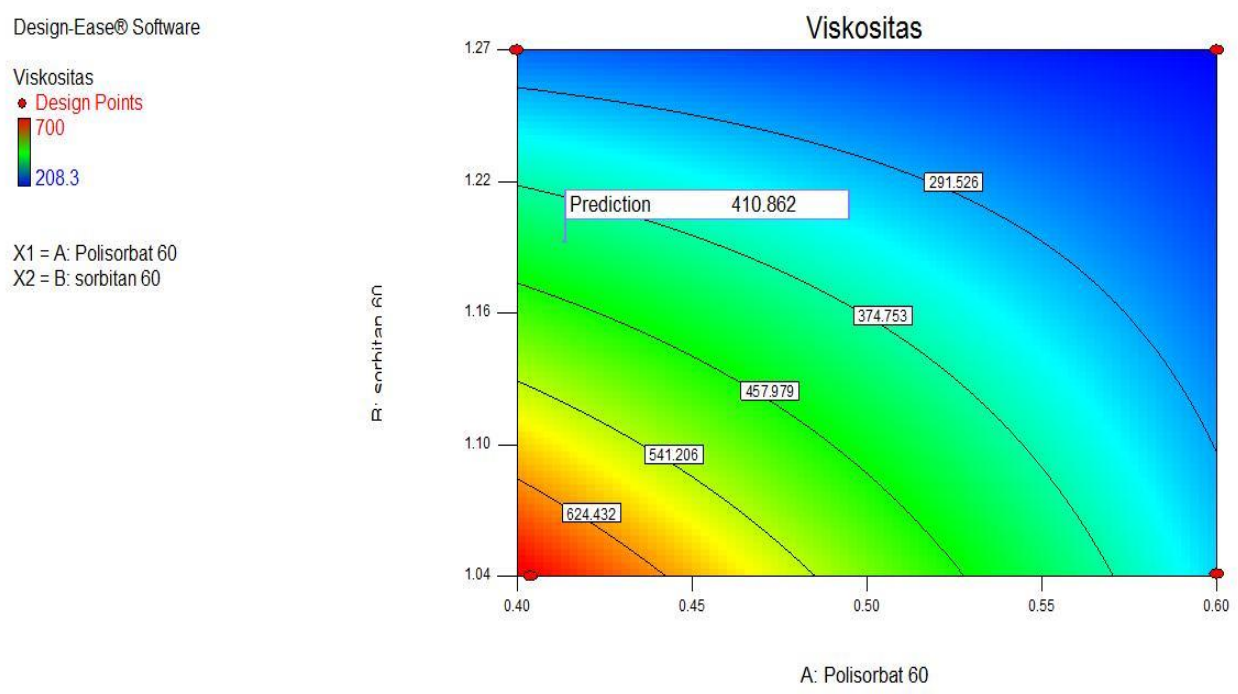

Gambar 1. Contour plot viskositas dua dimensi

Persamaan yang terkait dengan desain faktorial untuk respon viskositas krim adalah sebagai berikut:

$\mathrm{Y}=285,8+51,65 \mathrm{X}_{1}+23,35 \mathrm{X}_{2}-2,5 \mathrm{X}_{1} \mathrm{X}_{2}$

Persamaan $\mathrm{Y}$ diatas dapat digunakan untuk memprediksi komposisi kedua faktor pencampuran dalam pembuatan krim untuk menghasilkan respon pergeseran viskositas yang dikehendaki. Persamaan ini dapat dibuat contour plot dua dimensi seperti pada gambar 1, dari gambar tampak adanya area yang dapat dipilih (area yang diarsir warna hijau) yang merupakan area komposisi optimum antara polisorbat 60 dan sorbitan 60 . Respon viskositas dipilih 410,8 dPaS yang masih dalam range 208,3-700 dPaS.

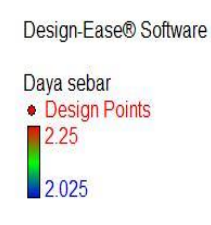

$\mathrm{X} 1=\mathrm{A}:$ Polisorbat 60 $\mathrm{X} 2=\mathrm{B}: \operatorname{sorbitan} 60$

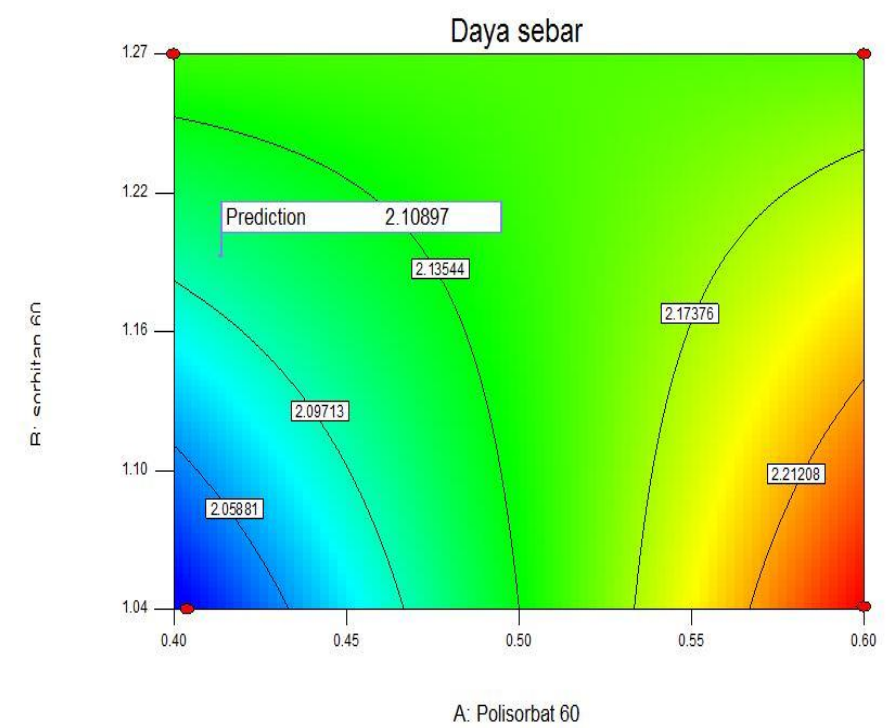

Gambar 2. Contour plot daya sebar dua dimensi 
Persamaan desain faktorial untuk respon daya sebar adalah:

$\mathrm{Y}=2,14-0,007 \mathrm{X}_{1}-0,05 \mathrm{X}_{2}-0,05 \mathrm{X}_{1} \mathrm{X}_{2}$

Pada gambar 2. memuat Contour plot daya sebar tampak area yang diarsir warna hijau yang berarti dipilih sebagai area komposisi optimum antara polisorbat 60 dan sorbitan 60 serta dapat menghasilkan respon daya sebar yang dikehendaki.
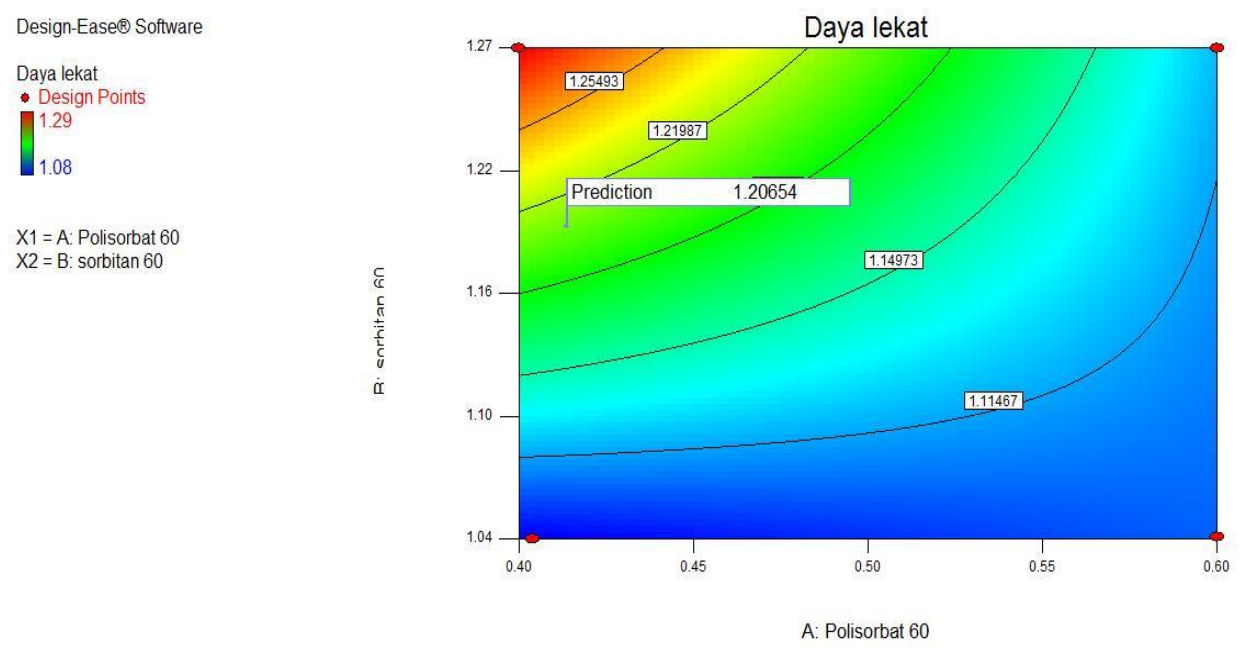

Gambar 3. Contour plot daya lekat krim dipilih pada warna hijau.

Persamaan desain faktorial untuk respon daya lekat krim adalah:

$\mathrm{Y}=1,14-0,05 \mathrm{X}_{1}+0,03 \mathrm{X}_{2}-0,04 \mathrm{X}_{1} \mathrm{X}_{2}$

Pada gambar 3. Contour plot daya lekat krim dipilih pada warna hijau sebagai area komposisi optimum serta dapat menghasilkan respon daya lekat krim yang dikehendaki.

Setelah didapat daerah yang dikehendaki masing-masing respon, dicari daerah yang komposisi dimana semua respon yang dikehendaki ada. Daerah tersebut disebut daerah komposisi optimum. Untuk mencarinya dibuat Overlay plot superimposed dari masing-masing contour plot respon yang ada, hasilnya pada gambar 4.
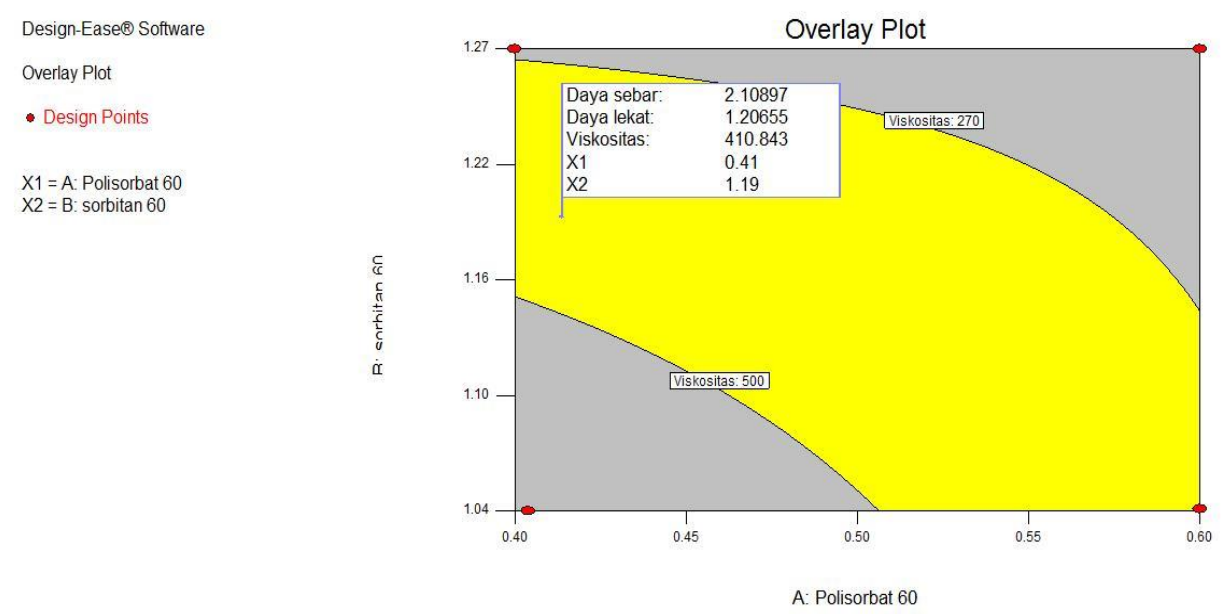

Gambar 4. Overlay plot formula optimum dua dimensi. 
Overlay plot superimposed (Gambar ) menunjukkan daerah komposisi optimum krim antibakteri ekstrak daun jengkol. Artinya untuk membuat krim dengan sifat fisik yang optimum dapat dibuat dengan komposisi 0,41 gram polisorbat 60 dan 1,19 gram sorbitan 60 .

\section{Stabilitas Fisik Formula Krim Optimum}

Uji sifat fisik krim dengan formula optimum dilakukan terhadap viskositas, daya sebar, daya lekat. Hal ini diharapkan formula optimum memiliki karakteristik fisik krim yang baik dari awal pembuatan dan waktu selama penyimpanan. Hasil prediksi sifat fisik krim dari basis polisorbat 60 dan sorbitan 60 berdasarkan Overlay plot superimposed adalah sebagai berikut.

Tabel 11. Hasil pembacaan uji krim komposisi optimum berdasarkan Overlay

\begin{tabular}{|c|c|}
\hline Sifat fisik & Prediksi \\
\hline Viskositas (d Pas) & 410,86 \\
\hline Daya sebar $(\mathrm{cm})$ & 2,10 \\
\hline Lamanya melekat gel (menit) & 1,20 \\
\hline
\end{tabular}

Hasil pengamatan viskositas krim optimum ekstrak daun jengkol terdapat pada tabel 12.

Tabel 12. Hasil rata-rata \pm SD pengamatan viskositas terhadap formula optimum krim ekstrak daun jengkol.

\begin{tabular}{cc}
\hline Waktu & Rata-rata \pm SD (d Pas) \\
\hline Minggu 0 & $396,6 \pm 15,2$ \\
Minggu 1 & $401,6 \pm 12,5$ \\
Minggu 2 & $391,6 \pm 24,6$ \\
Minggu 3 & $381,6 \pm 20,2$ \\
\hline
\end{tabular}

Hasil pengamatan daya sebar krim optimum ekstrak daun jengkol terdapat pada tabel 13.

Tabel 13. Hasil rata-rata \pm SD pengamatan daya sebar terhadap krim optimum ekstrak daun jengkol

\begin{tabular}{ccccc}
\hline \multirow{2}{*}{ Beban } & Minggu 0 & Diameter penyebaran $(\mathbf{c m} \pm$ SD) \\
& Minggu 1 & Minggu 2 & Minggu 3 \\
\hline 55,46 & $1,80 \pm 0,05$ & $1,84 \pm 0,04$ & $1,82 \pm 0,04$ & $1,85 \pm 0,05$ \\
105,46 & $1,88 \pm 0,03$ & $1,94 \pm 0,05$ & $1,92 \pm 0,04$ & $1,97 \pm 0,04$ \\
155,46 & $2,02 \pm 0$ & $2,06 \pm 0,05$ & $2,05 \pm 0,05$ & $2,13 \pm 0,01$ \\
205,46 & $2,09 \pm 0,02$ & $2,15 \pm 0,04$ & $2,12 \pm 0,04$ & $2,24 \pm 0,01$ \\
\hline
\end{tabular}

Hasil pengamatan daya lekat krim optimum ekstrak daun jengkol terdapat pada tabel 14. 
Tabel 14. Hasil rata-rata \pm SD pengamatan daya lekat terhadap krim optimum ekstrak daun jengkol

\begin{tabular}{cc}
\hline Waktu & Rata-rata \pm SD (menit) \\
\hline Minggu 0 & $1,30 \pm 0,05$ \\
Minggu 1 & $1,25 \pm 0,04$ \\
Minggu 2 & $1,23 \pm 0,05$ \\
Minggu 3 & $1,23 \pm 0,07$ \\
\hline
\end{tabular}

Semua hasil pengamatan yaitu viskositas, daya sebar dan daya lekat dilanjutkan analisis data menggunakna uji-t. Hasil yang didapatkan adalah ketiga uji tersebut mendapatkan hasil Signifikasi 2-tailed 0,25 untuk viskositas, Signifikasi 2-tailed 0,10 untuk daya sebar, Signifikasi 2-tailed 0,08 untuk daya lekat, dengan $\alpha=0,05$ Ketiganya menunjukkan $>0,05$, hal ini berarti tidak ada beda signifikan antara hasil prediksi dengan hasil uji yang dilakukan terhadap formula optimum krim (Gozali, 2012).

\section{Hasil uji aktivitas antibakteri}

Berikut adalah tabel hasil uji aktivitas antibakteri dari masing-masing formula.

Tabel 15. Hasil uji aktivitas antibakteri krim ekstrak daun jengkol.

\begin{tabular}{|c|c|c|c|c|c|}
\hline \multirow{3}{*}{ Formula } & \multirow{3}{*}{ Konsentrasi } & \multicolumn{3}{|c|}{$\begin{array}{c}\text { Diameter hambat } \\
(\mathbf{m m})\end{array}$} & \multirow{3}{*}{ Rata-rata } \\
\hline & & \multicolumn{3}{|c|}{ Replikasi } & \\
\hline & & 1 & 2 & 3 & \\
\hline Formula 1 & $3,13 \%$ & $12 \mathrm{~mm}$ & $12 \mathrm{~mm}$ & $13 \mathrm{~mm}$ & $12,3 \mathrm{~mm}$ \\
\hline Formula A & $3,13 \%$ & $12 \mathrm{~mm}$ & $13 \mathrm{~mm}$ & $12 \mathrm{~mm}$ & $12,3 \mathrm{~mm}$ \\
\hline Formula B & $3,13 \%$ & $11 \mathrm{~mm}$ & $11 \mathrm{~mm}$ & $11 \mathrm{~mm}$ & $11 \mathrm{~mm}$ \\
\hline Formula $\mathrm{AB}$ & $3,13 \%$ & $13 \mathrm{~mm}$ & $13 \mathrm{~mm}$ & $11 \mathrm{~mm}$ & $12,3 \mathrm{~mm}$ \\
\hline Formula optimum & $3,13 \%$ & $15 \mathrm{~mm}$ & $16 \mathrm{~mm}$ & $15 \mathrm{~mm}$ & $15,3 \mathrm{~mm}$ \\
\hline Kontrol negatif & & - & - & - & - \\
\hline
\end{tabular}

Data pada table diatas menunjukkan bahwa daya hambat pada masing-masing formula memberikan nilai yang berbeda meskipun konsentrasi sama. Hal ini karena pengaruh dari emulgator pada masing-masing formula. Jumlah emulgator yang berbeda akan menyebabkan proses pelepasan zat aktif yang berbeda. Pada masing-masing formula mempunyai konsentrasi emulgator yaitu polisorbat 60 dan sorbitan 60 yang berbeda. Konsentrasi polisorbat 60 dan sorbitan 60 inilah yang menyebabkan proses pelepasan obat yang berbeda. Dari hasil uji aktivitas antibakteri didapatkan nilai daya hambat yang terbesar yaitu pada formula optimum dengan nilai $15,3 \mathrm{~mm}$. Hal ini menjelaskan bahwa dengan emulgator polisorbat 60 sebanyak 0,41 gram dan sorbitan 60 sebanyak 1,19 gram untuk pembuatan krim sebanyak 30 gram mampu melepaskan zat aktif lebih bagus dibanding dengan formula yang lain. Selain itu pada formula optimum juga mempunyai stabilitas fisik yang lebih baik dari formula lainnya. Ini menjelaskan bahwa krim dengan stabilitas fisik yang baik mampu menhasilkan efek yang baik pula terhadap pengobatan. Karena zat aktif cepat terlepas dari pembawanya 
sehingga cepat terpenetrasi ke dalam lapisan kulit dan akhirnya akan memberikan efek yang maksimal terhadap pengobatan.

\section{SIMPULAN}

Dari hasil penelitian ini dapat disimpulkan bahwa secara metode factorial design dapat diperoleh krim ekstrak etil asetat daun jengkol dengan sifat fisik yang optimum dengan komposisi campuran emulgator polisorbat 60 sebanyak 0,41 gram dan sorbitan 60 sebanyak 1,19 gram. Krim ekstrak daun jengkol dengan formula optimum mempunyai diameter hambat rata-rata sebesar $15,3 \mathrm{~mm}$ terhadap Staphylococcus aureus ATCC 25923.

\section{SARAN}

Saran yang dapat diberikan oleh peneliti adalah perlu dilakukan penelitian dengan optimasi kombinasi polisorbat 60 dan sorbitan 60 dengan konsentrasi kadar yang lebih optimal. Perlu dilakukan uji daya antibakteri dengan menggunakan metode yang lain yaitu metode dilusi. Perlu dilakukan penelitian lebih lanjut tentang senyawa aktif dari etil asetat daun jengkol (Pithecollobium labatum Benth) yang aktif sebagai antibakteri secara in vivo.

\section{DAFTAR PUSTAKA}

Ali, S.M., \& Yosipovitch, G., 2013, Skin pH: From Basic Science to Basic Skin Care, Acta Derm Venereol, 93, 261-267.

Amalia, K.D. 2013. Isolasi, Identifikasi dan Uji Sensitivitas Staphylococcus aureus terhadap Amoxicillin dari Sampel Susu Kambing Peranakan Ettawa (PE) Penderita Mastitis Di Wilayah Girimulyo, Kulonprogo, Yogyakarta. Jurnal Sain Veteriner: 31(2).

Ansel H.C., 2014, Bentuk Sediaan Farmasetis dan Sistem Penghantaran Obat, 9th (eds). Afifah, H.\& Ningsih, T., Penerbit Buku Kedokteran EGC.

Anwar E., 2012, Eksipien Dalam Sediaan Farmasi Karakterisasi dan Aplikasi, Edisi Pertama., Dian Rakyat, Jakarta.

Badan POM RI, 2013, Pedoman Teknologi Formulasi Sediaan Berbasis Ekstrak, Volume 2., Badan Pengawasan Obat dan Makanan Republik Indonesia, Jakarta.

Ghozali, Imam. 2012. Aplikasi Analisis Multivariate Dengan Program IBM SPSS 20. Semarang: Badan Penerbit Universitas Diponegoro.

Maxiselly, Y. · A. Ismail · S. Rosniawaty · I.R.D. Anjarsari. 2015. Skrining fitokimia cangkang dan kulit batang tanaman jengkol asal Ciamis Jawa Barat sebagai inisiasi obat diabetes mellitus berbahan alam. Jurnal Kultivasi : 14(2).

Rosmala D. , Effionora A., Yunita K.S. 2014. Uji Stabilitas Fisik Formula Krim yang Mengandung Ekstrak Kacang Kedelai (Glycine max). Pharm. Sci. Res. $: 1(3)$. 
Salni, Marisa, H., Mukti, R.W. 2011. Isolasi Senyawa Antibakteri Dari Daun Jengkol (Pithecolobium lobatum Benth) dan Penentuan Nilai KHM-nya. Jurnal Penelitian Sains : 14(1).

Suwanda. 2011. Desain Eksperimen untuk Penelitian Ilmiah. Bandung: Alfabeta.

Wahyuning, S., Hanny, S., Dewi, A. 2016. Pemanfaatan Ekstrak Terstandardisasi Daun Som Jawa (Talinum Paniculatum (Jacq.) Gaertn) Dalam Sediaan Krim Antibakteri Staphylococcus Aureus. Jurnal Farmasi Sains Dan Komunitas : 13(1).

Yunitasari, D., Alifiar, I., Priatna, M. 2016. Uji Aktivitas Ekstrak Etanol Daun Jengkol (Pithecellobium Lobatum Benth) Terhadap Penyembuhan Luka Insisi Pada Tikus Putih Jantan Galur Wistar. Jurnal Farmasi Sains dan Praktis : 2(1). 